\title{
Exploring relationship between oil prices and renewable energy investments
}

\author{
A.A. Avramenko, \\ Cand. Sci. (Econ.) \\ e-mail:job_box2003@mail.ru \\ A.A. Mujumdar \\ e-mail: mujumdar.anita@gmail.com
}

\begin{abstract}
Subject/topic. The current paper explores the relationship between oil price and renewable energy investments basing on the example of six countries: USA, Germany, Japan, China, India and Brazil. Goals/objectives. The purpose of the research is to understand whether renewable energy investments reflect the dynamics of oil prices, and to explain the reasons for the findings. Methodology. The study examines the relationship for the four time intervals using correlation tables. It also establishes whether the correlation is influenced by the share of oil in country's electricity generation and net share of oil imports in energy use. Findings. The results show weak correlation between oil price and investments in renewables, as well as low significance of control factors almost in all studied cases. However, it was also found that there is a tendency for growing renewable energy investments in the period of high oil prices. Conclusions/relevance. The results prove findings from literature review and support overall understanding that in recent decades, renewable energy investments decoupled from oil prices. There are two main reasons for that: first, renewable energy investments are largely incentivized by subsidies and support schemes; second, renewables and oil compete on different markets. Practical significance. Findings of the paper can help various stakeholders to understand renewable energy market, as well as to make investment decisions in renewable energy.
\end{abstract}

Keywords: renewable energy, oil price, investments, correlation indices

\section{DOI: https://doi.org/10.33051/2500-2325-2020-1-116-125}

\section{Introduction}

The last decade has seen tremendous growth in renewable energy investment [14]. According to International Renewable Energy Agency (IRENA), between 2004 and 2016 the amount of funds allocated to clean energy worldwide increased five times, from $\$ 47$ bln to $\$ 242$ bln [11]. The organization named two main drivers for the investment growth, the first one being steadily declining costs for renewable energy equipment, and the second one - strong governmental support policies [10]. Another factor that cannot be neglected, though, is that renewable energy boom coincided with a period of high oil prices, which have started rapidly increasing in 2000s and reached their historical peak in 2011, with only a short time plummet in 2008-09 (Figure 1). 
BRENT CRUDE OIL

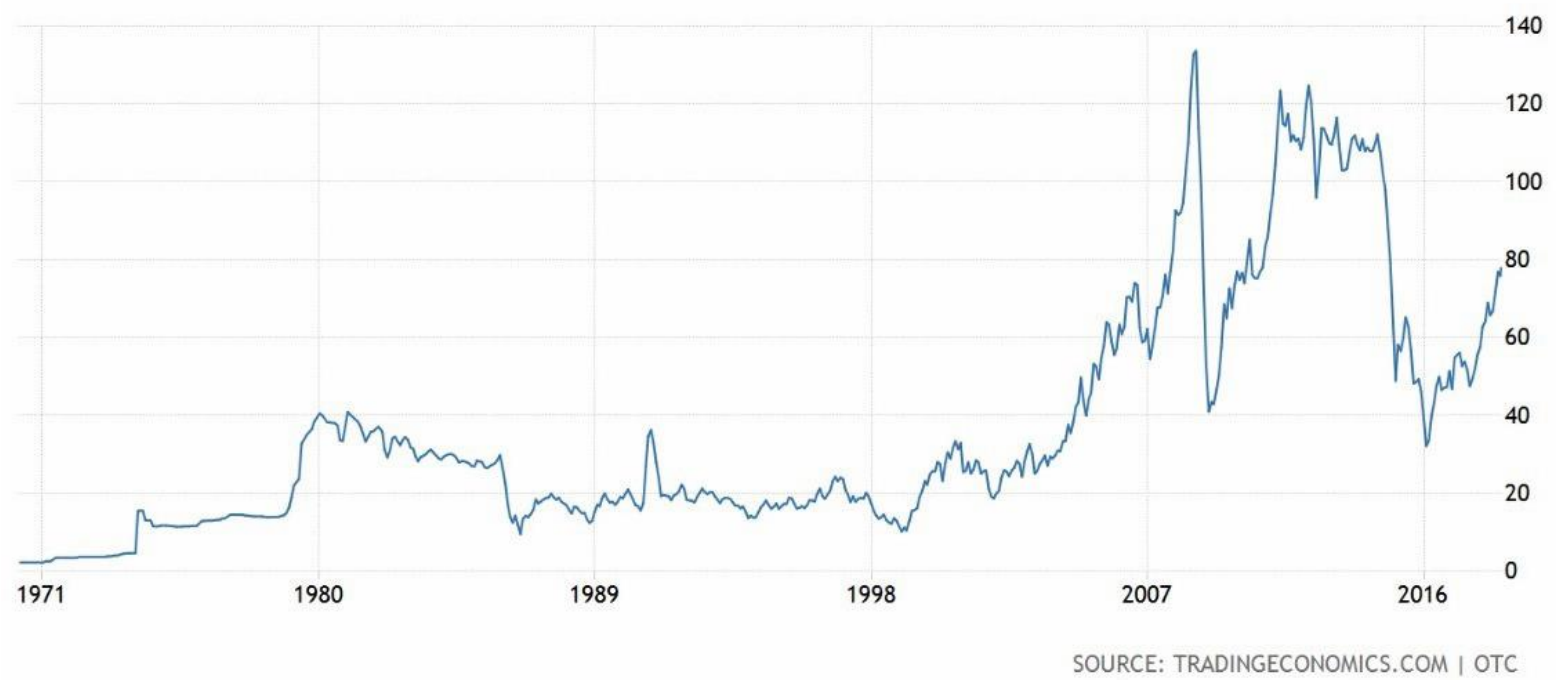

Figure 1. Historical data on Brent oil prices

Source: https://tradingeconomics.com/commodity/brent-crude-oil

Traditionally, from the 1970s, when renewables have only started to appear in developed countries, they have been largely associated with high oil prices. The reason for that is the costs for renewable energy at that time was quite high, and only when oil was expensive alternative sources could be cost-effective. Another factor is that oil importing countries (such as Europe and USA) considered renewables as a way to reduce vulnerability to oil price volatility and to strengthen their energy security. The peak of renewable energy investments in the USA occurred in 1976-1980, when in the light of oil shocks the country was struggling to reduce dependence on imported oil [6].

However, later in 1980s-1990s decreasing oil prices undermined nascent markets of renewables in California. It is also important to note that at that time oil had a relatively large share in electricity generation worldwide (about 20\% in 1976 and 11\% in 1990, according to the World Bank), which strengthened negative correlation between oil prices and renewable energy investments, as these energy sources were competing on the same markets. With that in mind, it comes as a no surprise that spurring oil prices in 2000s were followed by renewable energy investments. However, this decade saw an interesting event: in 2008-09, oil prices plummeted, but renewable energy investments decreased only slightly. Later, in the last quarter of 2014, oil prices fell again, but investments in alternative sources kept growing (Figure 2). Analyzing these phenomena, some experts stated that the development of renewables decoupled from oil prices and that «renewable energy has become more robust than ever».

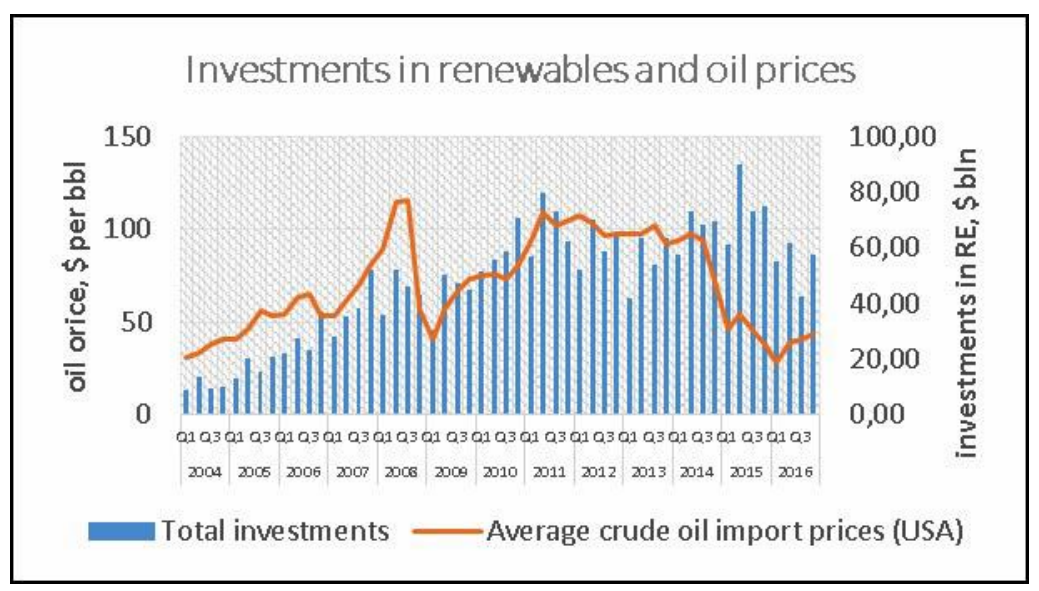

Figure 2. Investments in renewable energy and oil prices

Sources: Bloomberg New Energy Finance, IRENA, IEA database 
Experts from McKinsey, BNEF and EIA suggested several reasons why renewable energy stopped being sensitive to oil prices. First, the global share of electricity generated from oil sources decreased dramatically in most regions, which means that oil and renewables (with the exception of biofuels) stopped competing on the same markets. Second, renewable energy has been protected by strong support systems, which means that it does not compete with other sources entirely on market terms. Third, renewables have strong drivers - falling costs for equipment and improvements in storage technologies, which help to solve the problem of intermittency.

However, some questions remain unanswered. (1). Did the nexus between oil prices and renewable energy development break in 2014, or it happened earlier? (2). If one of the reasons that the nexus broke is that renewable energy and oil ceased competing on the same markets, did the relation persist in those regions where oil is still largely used for electricity generation (some countries in the Middle East, Latin America, etc.) (3)?. Would the relation between oil prices and renewable energy investments be the same for oil importing and oil exporting countries? This paper seeks to address these questions.

The remainder of the paper is organized in the following way. The next section presents a literature review on relationship between crude oil prices and renewable energy assets, as well as on regional differences in renewable energy investments. After this, we describe methodology of the study and discuss findings. Finally, the conclusion summarizes the results.

\section{Literature review}

Relationship between oil prices and behavior of renewable energy sector has been studied in academic literature, reports of international organizations and consultancies, as well as in master students' dissertations. Considering also studies [3, 4, 15-19, 21, 22], two main approaches were taken: the first one consisted in analyzing renewable energy investments, the other one dealt with stock prices of renewable energy companies. In one study the need for the latter was explained by two factors: first, investments are usually long-term, which is why they are not so sensitive to short-term changes in oil prices; second, decline in investments can be caused by market saturation in a certain region [2].

In the studies that looked into relationship between oil prices and stock of renewable energy companies, much attention was given to 2008-09 financial crisis: many saw it is as a watershed and a game-changing year. Some studies found that rising oil prices in early 2000s correlates with growing investments in renewables [2], it was also noted that oil peak in 2008 was coupled with the peak of renewable energy investments [8]. In the paper cited above, O. Alsayegh found evidence that from 2009 performance of renewable energy index RENIXX decoupled from oil prices, mostly because renewable technologies became more mature and turned into strategic choice for governments, including even those of oil exporting countries [2]. However, there were other opinions concerning "watershed years»: for example, a study by Managi \& Okimoto found evidence of a «structural break» in 2007 , when oil prices spurred, and proof of closer relation between renewable energy and oil prices in the aftermath of the «structural break» [12].

Several studies paid attention to regional difference in dynamics of renewable energy investments. Inchauspe et al. noted that during 2008-09 crisis investments decreased in Europe and USA, where renewables largely related on public and private market investments, but were not so much affected in Asia and Oceania, where government funding was more important. It led them to expect that government policies would be a significant factor influencing stock of renewable energy companies and the connection between renewable energy and oil prices [8]. O. Alsayegh also came to a conclusion that the relation between oil and renewables would largely depend on the region [2].

A couple of studies analyzed this relationship with a focus on particular regions. For example, a paper on the impact of low oil prices on renewable energy deployment in China showed that investments do decrease, however, it depends on the duration of low oil prices and their volatility [1]. A report that studied influence of low oil prices on renewable energy development in the Caribbean and in Latin America underlined the importance of whether the country is an oil importer or an oil exporter. More specifically, for oil exporting countries low oil prices mean decrease in budget revenues, which leaves less funds for investing in renewable energy, as investments are still largely dependent on government support. For oil importers, conversely, low oil prices could also reduce incentives to invest in 
renewables, as the oil is cheap [20]. An analyst at BNEF, however, believes that in case of strong political will low oil prices for oil importing countries such as India, Japan, China and European countries could have the opposite effect: «push up power demand, reduce political angst about energy bills, and increase the scope for further investment in clean energy» [5].

\section{Methodology and findings}

In this study, we attempted at answering the research questions posed in the introduction by analyzing data. We established relationship between renewable energy investments and oil prices on four intervals: 2004-2008 (3d quarter), 2009 ( $2^{\text {nd }}$ quarter $)-2011,2011-2014$ and 2015-2017 with the help of correlation matrix. The choice of periods was determined by the dynamics of oil prices: on the first two intervals, they were rising; on the third, they were declining; in 2015, a deep plummet occurred. Prices slightly recovered in 2016-17, however, we did not separate this period, because the number of samples would not be sufficient for analysis. We omitted the $4^{\text {th }}$ quarter of 2008 and the $1^{\text {st }}$ quarter of 2009, because oil prices took a deep plunge at this period, and it would be hard to expect that investments would follow immediately. Acknowledging the importance of regional differences, we made the analysis for six countries that are leading in renewable energy investments: USA, Germany, Japan, China, India, Brazil.

We also considered information on how much those countries relied on oil for electricity generation and net share of energy imports in total energy use. Basing on the literature review, we built a hypothesis regarding the impact of those two parameters on the correlation that we are interested in. We expected that in the country, which is 1) dependent on energy imports and 2) largely uses oil for electricity generation the correlation between oil prices and RE would be strong, as low oil prices would create incentive to generate electricity from oil. We also expected that in the country that is least dependent on energy imports and on oil for electricity generation this correlation would be the weakest. However, if a country is energy importer but does not generate electricity from oil, we did not expect the correlation between RE and oil prices to be strong, as renewable energy would rather be a «strategic choice» to ensure energy security [5].
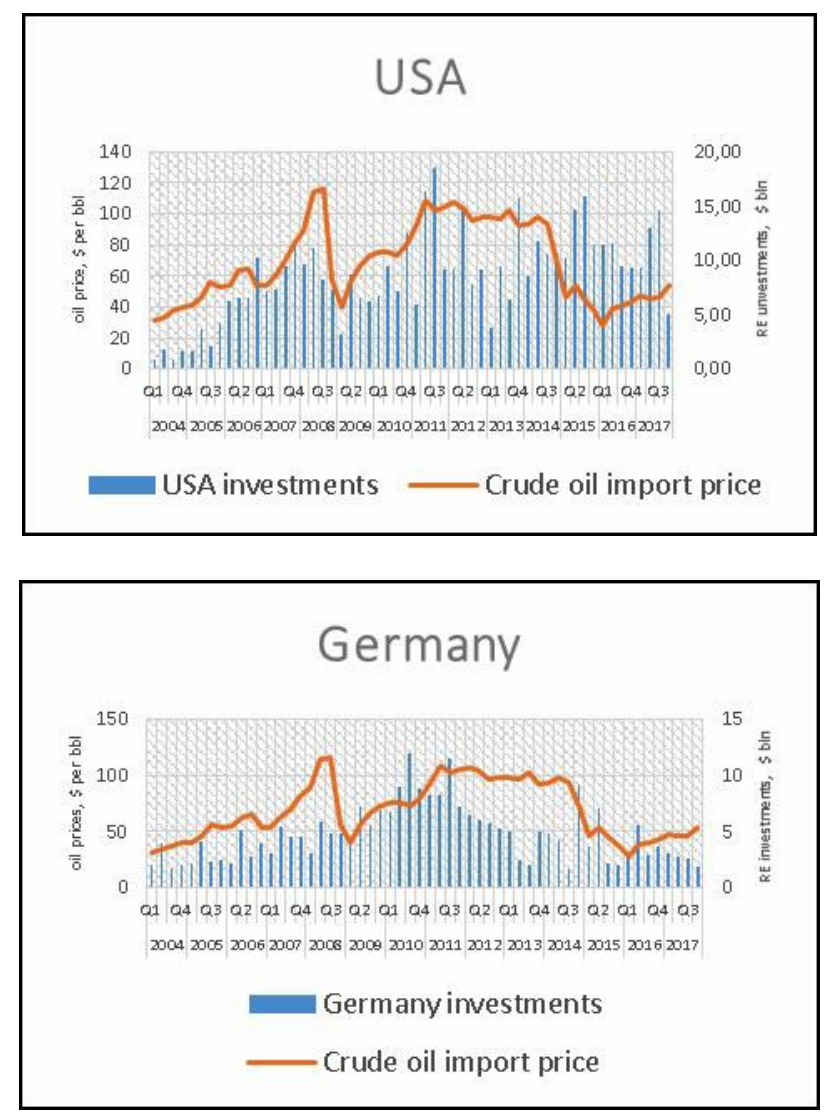

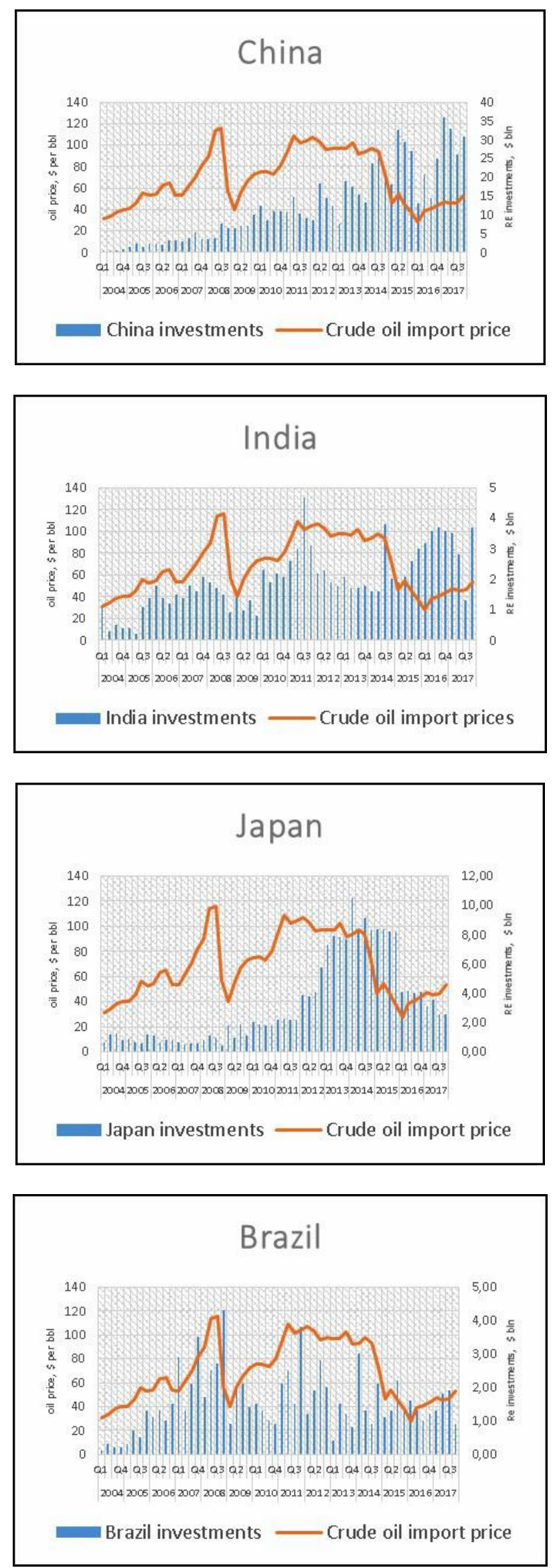

Figure 3-8. Investments in renewable energy and oil prices in different countries Sources: Bloomberg New Energy Finance, IRENA, IEA database 
Correlation indices between oil price and renewable energy investments

\begin{tabular}{|l|c|c|c|c|}
\hline & $\mathbf{2 0 0 4 - 2 0 0 8 ( 3 )}$ & $\mathbf{2 0 0 9}(\mathbf{2})-\mathbf{2 0 1 1}(3)$ & $\mathbf{2 0 1 1}(\mathbf{4})-\mathbf{2 0 1 4}$ & $\mathbf{2 0 1 5 - 2 0 1 7}$ \\
\hline USA & 0,77 & 0,69 & $-0,01$ & $-0,07$ \\
\hline Germany & 0,62 & 0,39 & $-0,1$ & 0,18 \\
\hline China & 0,83 & 0,72 & $-0,4$ & 0,7 \\
\hline India & 0,65 & 0,82 & 0,2 & $-0,2$ \\
\hline Japan & $-0,02$ & 0,76 & $-0,55$ & 0,06 \\
\hline Brazil & 0,75 & 0,31 & 0,01 & $-0,15$ \\
\hline
\end{tabular}

Correlation indices show that the strongest connection between renewable energy and oil prices existed before 2008, in the period of rising oil prices. It was found in all countries except Japan, which can be explained by the fact that only after Fukushima disaster in 2011 did the country's government introduce strong renewable energy policies [7]. In 2009-2011 correlation was quite strong in India, Japan, China and USA, but weaker in Germany. In case of Germany and Brazil, it can be explained by the fact that renewable energy investments slightly declined because of weaker support systems in the aftermath of 2008-09 financial crisis [9, 13].

In 2011-2014, correlation between oil and renewables was the weakest: investments did not react to decreasing oil prices and followed their own development path. In 2015-2017, however, more relation was found: Chinese investments turned out to be quite sensitive to both plummet in oil prices and their recovery. The fact that investments did not decline in 2011-14, but fell in 2015, supports findings of Alazraque-Cherni et al. that in China the relation between oil prices and RE investments depends on the volatility of prices [1]. In other countries, however, there was no significant correlation at that period.

Table 2.

Energy data for the selected countries

Source: World Bank database

\begin{tabular}{|l|c|c|}
\hline Country & $\begin{array}{c}\text { Share of oil in electricity generation, \%, } \\
\text { average (2004-14) }\end{array}$ & $\begin{array}{c}\text { Net share of energy imports in energy } \\
\text { use, \%, average (2014-14) }\end{array}$ \\
\hline USA & 1,6 & 22 \\
\hline Germany & 1,5 & 60,2 \\
\hline Japan & 14 & 85,4 \\
\hline China & 0,8 & 10,3 \\
\hline India & 2,7 & 27,4 \\
\hline Brazil & 3,5 & 9,3 \\
\hline
\end{tabular}

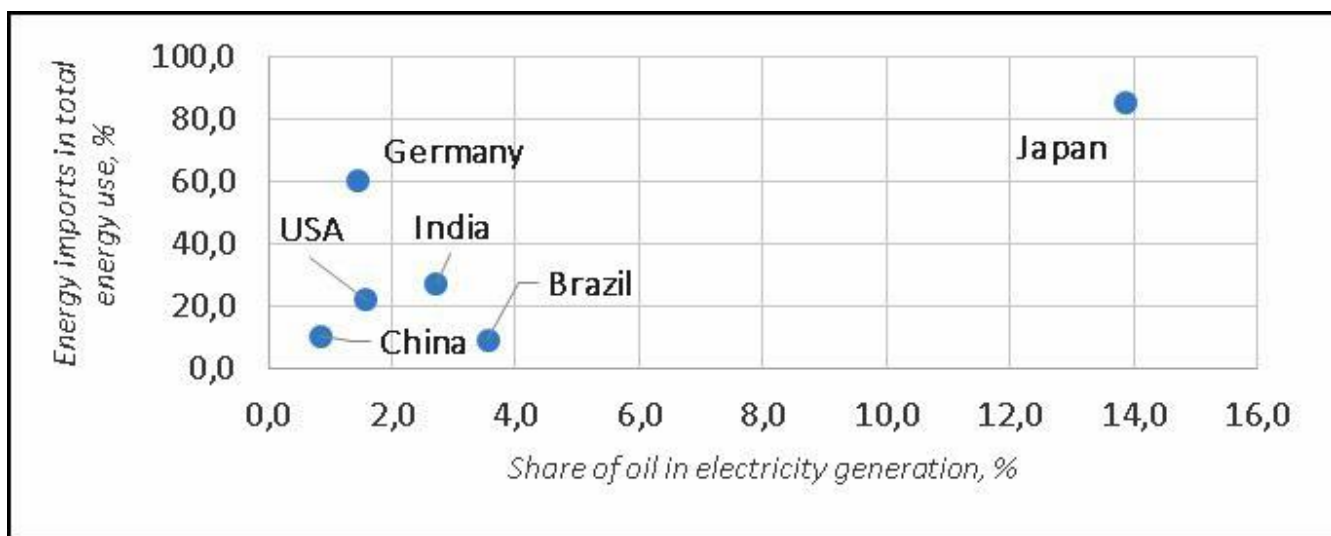

Figure 9. Energy data for the selected countries

Source: World Bank database

Проблемы рыночной экономики. - 2020. - № 1. - С. 116-125. 
As for the hypothesis set above, it turned out to be wrong. We expected that Japanese investments in RE would have the strongest correlation with oil prices, as the country is energy importer and has quite a large share of oil in electricity generation. It turned out, however, that in this country the correlation was present only in 2009-11. It probably means that investments were driven by strong government support and not by market dynamics of oil prices.

We also expected that in China relationship between oil prices and RE would be weak, as the country almost does not use oil for electricity and has relatively little share of imported energy in energy consumption. However, it turned out that in China this correlation is the strongest: it was found in 3 out of 4 periods. This finding might mean that we should have taken the data on oil imports only, instead of all energy imports, as China is very reliant on oil imports.

The findings from other countries also failed to prove the hypothesis. We expected that Germany would have a stronger correlation than USA, because it is more reliant on energy imports, but it turned out to be the other way round. Brazil, which ranked second after Japan in use of oil for electricity, showed correlation only in the first period.

All in all, this study indicates that the factors which we chose are not the most significant determinants in renewable energy deployment. Rising oil prices might still be an incentive for larger investments in RE, but declining prices do not have significant influence. It turns out that the extent to which the country relies on oil imports and oil for electricity generation is also not very important though, there needs to be a larger sample of countries to test this hypothesis more accurately. Still, however, we can agree that renewable energy investments are more dependent on the country's individual policies and governmental decisions.

\section{Conclusion}

This study sought to examine relationship between oil prices and renewable energy investments in six countries, which are leading in renewable energy development. The link was tested by the means of correlation matrices for four periods. The main finding is that the relation was strongest in 2004-2008 except for Japan, which did not have strong RE investments at that time. It was also established that when oil price is on the rise, investments in renewables go along with it; however, decreasing oil prices in most cases show no correlation with renewable energy investments. The exception, however, is China: in 2015-17 investments in RE had significant correlation with oil price, which somewhat agrees with findings of Alazraque-Cherni et al.

The assumption that share of oil for electricity generation and country' dependence on imported energy would influence the correlation rate between oil prices and renewable energy investments proved to be almost wrong. Japan - the country with the highest values for both variables - showed the smallest correlation between oil price and renewables, except 2011-2014, when renewable energy investments in the country were growing because the country wanted to diversify from nuclear energy. China, however, having the lowest values for the two variables, turned out to have strong correlation between oil price and renewable energy investment in 3 out of 4 periods. This might mean an error in data selection - we might have needed to take data on oil imports only, not all energy imports.

In general, we can say that this study proves weak correlation between oil prices and renewable energy investments. It proves findings in other literature, which state that nowadays investments in renewables are driven mostly by falling costs and strong support systems. We believe that this finding is positive for renewable energy, as it shows that renewables can develop independently from volatility of oil prices. However, additional research should be done for biofuels: oil is their direct substitute, which means that low oil prices might have a stronger influence on investments. Finally, we should keep in mind that in the future electric vehicles also can become a game-changer in relations between oil and renewable energy.

\section{References}

1. Alazraque-Cherni J., He J., Rosillo-Calle F. Renewable energy investment in China: the impact of low oil prices // Economic and Political Studies. - 2016. - July. - Vol. 4. - No. 3. - Pp. 278298. (In English).

2. Avramenko A.A., Tulupov A.S., Petrova L.V. Structuring of environmental pollution costs // Regional problems of economic transformation. - 2015. - No. 7. - Pp. 46-59. (In Russian). 
3. Astanina L.V., Avramenko A.A., Tulupov A.S. Problems of environmental risk assessment: factor analysis // Materials of the Seventh International forum «Russia in the XXI century: global challenges and prospects of development». - 2018. - Pp. 323-328. (In Russian).

4. Alsayegh O.A. Ramification of Oil Prices on Renewable Energy Deployment // International Journal of Economics and Management Engineering. - 2016. - Vol. 10. - No. 6. - Pp. 1828-1832. (In English).

5. Bloomberg New Energy Finance. Oil price plunge and clean energy - The real impact // Bloomberg NEF. - 2014. (In English).

6. Dooley J. U.S. Federal Investments in Energy R\&D: 1961-2008 // U.S. Department of Energy, 2014, Oct. - 19 p. (In English).

7. Harlan C. After Fukushima, Japan beginning to see the light in solar energy // The Guardian. - 2013. (In English).

8. Inchauspe J., Ripple R.D., Trück S. The Dynamics of Returns on Renewable Energy Companies : A State-Space Approach // Energy Economics. - 2015 - Vol. 48. (In English).

9. Institute for Energy Research. Europe Slashing Renewable Subsidies // IER, 2014. (In English).

10. International Renewable Energy Agency. Global landscape of renewable energy finance // IRENA, 2018. - 44 p. (In English).

11. IRENA Resource. Data and Statistics. IRENA. [Electronic recourse]. - URL: http://resourceirena.irena.org/gateway/dashboard/?topic=6\&subTopic=11 (Access date: 10 Aug. 2019, In English).

12. Managi S., Okimoto T. Does the price of oil interact with clean energy prices in the stock market? // Japan World Economy. - 2013. - Aug. - Vol. 27. - Pp. 1-9. (In English).

13. Martins F., Gay J.C. Biofuels: From boom to bust? // Bain \& Company - 2014. (In English).

14. Mudretsov A.F., Tulupov A.S. The Questions of development of alternative energy in Russia // Vestnik TSU. - 2016. - No. 4. - Pp. 38-45. (In Russian).

15. Mudretsov A.F., Tulupov A.S. Problems of development of non-traditional and renewable energy sources // In the collection: Strategic planning and development of enterprises. - Moscow: CEMI RAS, 2016. - Pp. 100-103. (In Russian).

16. Mudretsov A.F., Tulupov A.S. On the economic efficiency of non-traditional and renewable energy sources //In the collection: Strategic planning and development of enterprises. - Moscow: CEMI RAS, 2017. - Pp. 113-115. (In Russian).

17. Mudretsov A.F., Tulupov A.S. Unconventional and renewable energy sources in the new technological way of modern Russia // Regional problems of economic transformation. - 2016. - No. 11. - Pp. 12-20. (In Russian).

18. Mudretsov A.F., Tulupov A.S. Improving the economic efficiency of alternative and renewable energy sources // Regional problems of economic transformation. - 2017. - No. 5 (79). - Pp. 1219. (In Russian).

19. Mudretsov A.F., Tulupov A.S. Computer program for the feasibility study of investment projects of alternative and renewable energy // Materials of the international scientific-practical conference «Modeling of scientific and technological development in the conditions of nonlinear macroeconomic dynamics». - 2018. - Pp. 131-133. (In Russian).

20. Reis C.M. Will the expansion of wind and solar energy sources resist the fall in oil prices? An overview of Latin America and the Caribbean. // Regional Programme Energy Security and Climate Change in Latin America and Konrad Aderanuer Foundation, 2016. - 34 p. (In English).

21. Tulupov A.S., Petrov I.V. Fuel and energy complex and methods for assessing the harm from air pollution // International Scientific Conference «Knowledge-based technologies in development and utilization of mineral resources», IOP Conference Series, 2018. DOI: 10.1088/17551315/206/1/012054. (In English).

22. Tulupov A.S., Mudretsov A.F., Prokopyev M.G. On the methods for calculating the size of harm to the environment, caused by Air pollution // Ecology and Industry of Russia. - 2019. - No. 6. Pp. 41-45. DOI: 10.18412/1816-0395-2019-06-41-45. (In English). 
About authors

Avramenko Andrey Alekseevich, Cand. Sci. (Econ.), Assoc. Prof., Department of International Complex Problems of Nature Management and Ecology, Moscow State Institute for International Relations (MGIMO University), Moscow.

Mujumdar Anita, juniour research fellow, Center for Sanction Policy Expertise, Institute for International Studies, MGIMO University, Moscow.

\title{
For citation
}

Avramenko A.A., Mujumdar A.A. Exploring relationship between oil prices and renewable energy investments // Market economy problems. - 2020. - No 1. - Pp. 116-125 (In English).

DOI: https://doi.org/10.33051/2500-2325-2020-1-116-125

\section{Изучение взаимосвязи между ценами на нефть и инвестициями в возобновляемые источники энергии}

\author{
А.А. Авраменко, к.э.н. \\ e-mail: job_box2003@mail.ru \\ A.A. Муджумдар \\ e-mail: mujumdar.anita@gmail.com
}

\begin{abstract}
Аннотация
Предмет/mема. В данной статье исследуется взаимосвязь между ценами на нефть и инвестициями в возобновляемые источники энергии на примере шести стран: США, Германии, Японии, Китая, Индии и Бразилии. Цели/задачи. Цель исследования - проанализировать, отражается ли динамика цен на нефть в инвестициях в ВИЭ, а также объяснить причины полученных результатов. Методология. Взаимосвязь исследуется на четырех отрезках времени с помощью корреляционных таблиц. Кроме того, анализируется, насколько на эту связь влияют дополнительные параметры: доля нефти в выработке электроэнергии в стране и доля импорта нефти в потреблении энергии. Результаты. В ходе исследования было обнаружено, что связь между ценами на нефть и инвестициями в ВИЭ в целом довольно слабая. Дополнительные параметры также оказались не очень существенными. Однако, было обнаружено, что в период роста цен на нефть существует тенденция к увеличению инвестиций в ВИЭ. Выводы/значимость. Результаты исследования подтверждают выводы других исследователей о том, что в последние десятилетия цены на нефть перестали оказывать сильное влияние на инвестиции в ВИЭ. Выделяют две основные причины: прежде всего, инвестиции в ВИЭ стимулируются главным образом государственными субсидиями и системами поддержки; во-вторых, ВИЭ и нефть не являются прямыми конкурентами на рынке. Применение. Результаты данной статьи могут быть использованы для более глубокого понимания рынка ВИЭ в разных странах и для принятия решений касательно инвестиций в возобновляемые источники энергии.
\end{abstract}

Ключевые слова: ВИЭ, возобновляемая энергетика, иены на нефть, инвестиции, коррелячионные индексы

\section{Об авторах}

Авраменко Андрей Алексеевич, к.э.н., доцент кафедры Международных комплексных проблем природопользования и экологии Московского государственного института международных отношений (МГИМО), Москва. 
Муджумдар Анита Ашоковна, младший научный сотрудник Центра экспертизы санкционной политики Института международных исследований МГИМО, Москва.

\section{Для цитирования:}

Авраменко А.А., Муджумдар А.А. Изучение взаимосвязи между ценами на нефть и инвестициями в возобновляемые источники энергии // Проблемы рыночной экономики. -2020 . - № 1. - C. 116-125 (In English).

DOI: https://doi.org/10.33051/2500-2325-2020-1-116-125 